\title{
Level of Rural Development in Burdwan and Murshidabad Districts, West Bengal: A Comparative Study
}

\author{
Mr. Syfujjaman Tarafder ${ }^{\dagger}$ and Dr. Narayan Chandra Jana ${ }^{\top}$
}

\begin{abstract}
The key purpose of this research is to examine the level of attainment of rural development in the two districts-Burdwan and Murshidabad. The reasons for selecting these two districts stems from the fact that majority of the population of these two districts dwell in rural areas. The concept of rural development is comprehensive. It includes economic development of rural people through the development of productive sectors and employment associated with rural infrastructural development as well human development. Therefore, rural development includes in its domain all the aspects of human development of the rural people. The present Central as well as State Governments have undertaken different policies and plans to bring about positive changes amidst the rural people. In most cases, however, the policies and plans fail to achieve the desired level of changes in the rural areas (Desai, 1991). Although in fewer isolated cases, some success has been achieved, but overall development remains to be reached. This research, based mainly on secondary data aims to investigate the scale of progress in the two districts-Burdwan and Murshidabad of West Bengal, India, in the areas embracing social correlates of rural poverty, basic infrastructure facilities, standard of living and quality of life. The data are analysed with the help of statistical and cartographical analysis.
\end{abstract}

Key words: Rural Development, Human Development Indicators, Standard of living, Burdwan, Murshidabad, West Bengal, India

\section{Introduction}

According to the World Bank, "rural development is a strategy designed to improve the economic and social life of a specific group of people- the rural poor" (Desai, 1991: p.1.1).

The first Prime Minister of India understood the necessity of removing poverty from rural India and therefore, from the first five year plan, the government emphasised on the development of sectors related to rural India - agriculture, rural employment, rural infrastructure, rural housing, financial sector, etc. (Desai, 1991) alongside a long list of policies and programmes evolved during the 69 years of independence. Despite all these policies and programmes, the situation remains deplorable except for some recent infrastructural developments. Even the conditions of people living below poverty line (BPL) did not change considerably.

From the beginning of the Community Development Programme of the first Five Year Plan to the most recent "Bharat Nirman" programme of the $10^{\text {th }}$ and $11^{\text {th }} 5$-Year Plans, the approach followed for planning is 'top-down'. In this approach, plans are set by the top-level administration without knowing and sometimes ignoring the regional diversities of India and the actual need of the people at grass-root level. Thus, all the plans of top-down approach have often failed to bring the desired result in the development of villages. Here, West Bengal is no

\footnotetext{
${ }^{+}$Assistant Professor in Geography, Gour Mahavidyalaya, Malda, West Bengal, India, Email: soheltfd@gmail.com

${ }^{\top}$ Associate Professor \& Ex-Head, Department of Geography, The University of Burdwan, Burdwan-713104, West Bengal, India, Email: jana.narayan@gmail.com

(C) 2016 Tarafder and Jana. This is an Open Access article distributed under the terms of the Creative Commons Attribution License (http://creativecommons.org/licenses/by/2.0), which permits unrestricted use, distribution, and reproduction in any medium, provided the original work is properly cited.
} 
exception; rather the situation of the rural poor in the state is perplexing.

Therefore, it remains paramount to examine the status of the rural areas in the districts of West Bengal in terms of economic and social indicators:

- evaluating the implementation of the government schemes and programmes of both the central and the state,

- probing the actual problems of backwardness and failure or success of the schemes and programmes of the governments, and

- assessing the role of the Panchayats in this regard to assess a true developmental approach for all the districts that could be perhaps replicated in other districts of the country.

Here, of course we limit our research to the districts of Burdwan and Murshidabad. While Murshidabad lies in between the latitude $23^{0} 43^{/ 3} 30^{/ /}$and $24^{0} 50^{\prime} / 20^{/ /} \mathrm{N}$ and longitude $88^{\circ} 46^{\prime}$ and $87^{\circ} 49 / 17^{/ / E}$ with Berhampore as the district headquarter, Burdwan extends from $22^{\circ} 56^{\prime}$ to $23^{\circ} 53^{\prime}$ North latitude and from $86^{\circ} 48^{\prime}$ to $88^{\circ} 25$ East longitudes with Bardhaman as the district headquarter. According to the Census 2011, in Murshidabad district there are 2210Mouzas (Revenue village), out of which 1886 are inhabited, embracing 254 gram panchayats. The total area of Murshidabad is $5324 \mathrm{sq} . \mathrm{km}$. and a home to a total population of 7103807 out of which $80.28 \%$ is rural. In Burdwan, there are 2529 Mouzas (Revenue villages), out of which 2438 are inhabited and 277-gram panchayats covering a total area of $7074 \mathrm{sq} . \mathrm{km}$ with a total population of 7723673 , out of which $60.13 \%$ is rural.

The paper begins with a review of literature. This follows a discussion of rationale for the selection of the study area, while highlighting the objectives of the study. It then goes on to discuss the indicators-rural economy and poverty, human development indicators, basic infrastructure facilities, standard of living and quality of life. Finally, combining all the indicators of development, composite scores are calculated in order to compare the levels of rural development between the two districts of Burdwan and Murshidabad.

\section{Review of Literature}

The phrase 'rural development' is widely used among the administrators, policy makers and academicians. Notwithstanding, Visva-Bharati University was built by Nobel Laureate Rabindranath Tagore built with an aim to reconstruct the village of Sriniketan, located at a distance of 3-km from Santiniketan to transform it into a village of "self-reliant and selfrespectful, acquainted with the cultural traditions with their own country and competent to make an efficient use of modern resources for the improvement of their physical, intellectual and economic conditions" (Sinha, 2016: p.02). In addition, the Gandhian model of development could provide solutions to the rural problems which are linked to the basic needs of the people-'Annna (livelihood), 'Akshar' (literacy), 'Arogya' (health) and 'Acharan' (moral value). Against these backdrops, the present Central as well as State Governments has undertaken different policies and plans to bring about positive changes amidst the rural people. Nonetheless, it remains well documented that from the days of pre independence until now, a number of different flagship programmes and schemes have been undertaken targeting different sectors of rural economy (Singh, 2014). For examples, Jawahar Rozgar Yojana (JRY) now Jawahar Gram Samriddhi Yojana (JGSY), Integrated Rural Development Programme (IRDP) now Swarnajayanti Gram Swarozgar Yojana (SGSY), Indira Awas Yojana (IAY), Pradhan Mantri Gram Sadak Yojana (PMGSY), National Rural Livelihood Mission (NRLM), National Rural Employment Guarantee Act (NREGA) now Mahatma Gandhi National Rural Employment Guarantee Act (MGNREGA), etc. (Bhattacharyya et al., 2011; Bhattacharyya and Vauquline, 2013; Fraser, 2015; Goswami and Bhattacharyya, 2014; Sudarshan, 2011; Singh, 2014) for improving the conditions of the rural people. Community Development Programme (CDP) that started in October 1952 was the first and largescale programme towards rural development by 
the Government of India (Planning Commission, Gol; Desai, 1991; Singh, 2014). The CDP adopted systematic integrated approach to rural development with a hierarchy of village-level workers and block-level workers drawn from various fields to enrich rural life. Nehru viewed community development as the way to involve the village people in building a new India (Singh, 2014). 5000 National Extension Service (NES) blocks were created under CDP by the end of second five year plan (Desai, 1991). Main objective was to secure the total development of the material and human resources of rural areas (Singh, 2014). Third five-year plan was characterised by a series of developmental schemes through allocations under the NES programme. This was succeeded by Small Farmers Development Agencies, Marginal Farmers Development Agencies, Cash Schemes for Rural Employment, Food for Work Programme, Drought prone Area Programme and Desert Development Programmes in the early and late seventies (Desai, 1991; Singh, 2014).

In order to alleviate people from acute forms of poverty, anti-poverty strategies were adopted in the sixth five year plan as the theory of trickle down benefits (the spill-over mechanism or spread effect which means unrolling of development towards the periphery from the growth centre) for general development, but failed to accrue success (Desai, 1991).

In 1960-61, in order to transform the rural areas and to increase the production of food crops, Intensive Agricultural District Programme was undertaken following Intensive Agricultural Area Programme (Planning Commission, Government of India). To achieve this, HYV seeds were adopted and the farmers were trained under Farmers' Training and Education Programme in 1964. To develop village industries, Village Industries Programme was launched in 1964 followed by Village Artisans' Programme in 1970-71. One thing should be stated here that the Government of India formed All India Khadi and Village Industries Board in 1953 (Basu et al., 1995). Rural Link Road Programme was launched in the late 1970s to develop its transport and communication system.
Minimum Needs Programme (MNP) was launched in the Fifth Five Year Plan to provide public services, facilities and amenities to the rural people who remain in a disadvantageous position than their urban counterparts (Singh, 2014).

To increase the income of the rural poor, National Rural Employment Programme and Rural Landless Employment Guarantee Programme was taken in the sixth plan (19801985). In 1989, these two were merged into a single Jawahar Rozgar Yojana (Desai, 1991; Planning Commission, Gol; Singh, 2014). Indira Awas Yojana was launched in the seventh plan (1985-1990) to provide house to houseless and the poor. Pradhan Mantri Gram Sadak Yojana is an important programme for upgrading rural roads to an all-weather road in order to reduce communication gap (Singh, 2014) which was later integrated with the most comprehensive rural development programme in the tenth (2002-2007) and eleventh plan (2007-2012) periods is "Bharat Nirman" basically to develop basic five components of rural infrastructure like electricity, road, drinking water, telephone, irrigation and housing (Singh, 2014). In addition, Sarva Shiksha Abhiyan (Education for all)and then the Right to Education Act enacted on 4 August 2009 making education free and compulsory for children aged 6-14 years, and as mentioned above Mahatma Gandhi National Rural Employment Guarantee Act, 2006 a pro poor scheme for providing employment for work seeking rural poor are the recent programmes. In West Bengal, "Operation Barga" (Land Reform Programme of the Government of West Bengal in order to provide land to the landless poor people to arrest poverty, launched in the year, 1977) was a massive and successful programme for providing land to land less by land ceiling (De and Jana, 1997), yet poverty refuses to die. However, as stated elsewhere, all these programmes are implemented using top-down approaches.

Hence, due to lack of robust bottom up approaches the desired level of development fails to be achieved. Until now, most of the programmes are taken centrally and imposed 
over diversified rural areas. Another problem is about implementing bodies and agencies, where massive level of corruption have surfaced and free flow of government aids are being hampered.

To achieve development of the rural people, infrastructure development is mandatory (Srinivasan, 2010). Infrastructure consists of both physical and social components such as basic education, primary health and a pollution free ambience always taking precedence over the physical infrastructure (Srinivasan, 2010). Social infrastructure can never be securely built if physical infrastructure such as sound roads, sanitations, employment sectors remain weak (Malyadri, 2010; Srinivasan, 2010). Srinivasan (2010) emphasised on the need of rural infrastructure development for effective enhancement of rural livings and he mentioned the government initiatives with an account of target and achievements. The need of rural road connectivity as a stimulant for rural poverty reduction (Yadav, 2010). Roads have direct links with the rural development and poverty has a strong link with isolation (Yadav, 2010). Transport is important for building the human capital of the poor by facilitating access to social services such as health, education, clean water and basic administrative services (Malyadri, 2010; Yadav, 2010). The valuable findings of Malyadri (2010) in his paper entitled "Rural Infrastructure: An Engine for Poverty Mitigation" is the demand-supply gap and several critical implementation issues. He stressed upon the drawbacks of top down approach of most Indian rural developmental programmes.

Bhattacharaya (2011) successfully applied Principal Component Analysis (PCA) techniques to find out social factors that are related to rural poverty as well as social indicators to derive policy suggestion so that social indicators could be targeted to reduce poverty. She used three indices-social deprivation index, infrastructural availability index and health availability index and correlated them with poverty to examine the most important one and found health as the most important determining factor of rural poverty (Bhattacharaya, 2011). Here, we argue that the corporate sectors (both private and public companies) have their own social responsibilities to uplift poor rural and downtrodden people to lift out of poverty as an ethical way of giving back to the society. Nonetheless, it remains a part of their business model (Pradhan et al., 2010). Chakrobarty (2010) made a valuable research on the 'Chitrakoot Project', Madhya Pradesh where Deendayal Research Institute (DRI), an NGO, have improved poor rural people's lives by increasing their irrigated area and the water level covering 500 villages. Here, farmer's family income increased manifold by implementing watershed management schemes, agro forestry, local level seed production, etc. In addition, the project also took initiatives to enhancing farmers' skill by active training on farming, marketing of agricultural products, packaging, etc. and forming Self Help Groups (SHGs). Therefore, we argue that Chitrakoot Project is a comprehensive rural development project, which can perhaps be successfully implemented as a development model in other parts of India (Chakrobarty, 2010) including West Bengal and of course the study areas, that is, Burdwan and Murshidabad.

Very little research on different issues of rural development of Murshidabad and Burdwan are found-for instance, Kundu (2012) argued that Murshidabad district faces immense labour out migration, which has serious negative impacts on its agriculture, industry, construction, transport and communication. The worst affected sector is agriculture (Kundu, 2012). Kundu (2012) goes on to show that wage pattern (having highest coefficient value in logistic regression model) is the most important push factor to push rural people to migrate. Similarly, Mukherjee et al., (2012) provides a valuable study on SHGs in the district on a sample basis under the scheme of SGSY and investigate the functioning of the SHGs. Most of the SHGs failed to achieve the goal set by SGSY scheme in the district as most of the SHGs work in mid-day meal scheme, etc. and have failed to increase their family earnings. Another important finding of this study is that the SGSY scheme does not attract the poorest family members and 
thereby, failed to achieve the SGSY goals (Mukherjee et al., 2012).

These studies are however, piecemeal types and based on small samples. There is a research gap of conducting comprehensive study in these two districts following regional approach. Hence, we attempt for a comprehensive analysis of the issues of rural development-rural infrastructure (physical as well as socio-cultural) including poverty, unemployment, illiteracy, agricultural development and rural tourism. In other words, the current research aims at examining the extent of rural development in the realms of rural poverty, basic infrastructure facilities, standard of living and the quality of life in the districts of Murshidabad and Burdwan, West Bengal.

\section{Rationale for Selection of the Study Area}

Burdwan and Murshidabad are two districts in West Bengal where most of the population lives in rural areas. However, in terms of general development Burdwan ranks higher than Murshidabad. Burdwan is more developed agriculturally in the government reports than Murshidabad. Burdwan is also developed industrially. The eastern part of the district is enriched in alluvial soil of the River Bhagirathi (one of the minor streams of the River Ganges) and Damodor River (a tributary to the River Bhagirathi) and is one of the most productive agricultural regions in West Bengal. The western part of the district is rich in coal and other mineral resources. This part is highly industrialised and contains various factories based on iron and steel processing, as well as many cement factories. Durgapur, Burnpur, and Kulti are in the western part of the district. It also contains power plants at Durgapur and Dishergarh. On the contrary, Murshidabad district is agro-based. Most of the people here depend on agriculture and allied activities for their livelihood. The district is backward industrially among the districts of West Bengal. No large-scale industry is there except for Sagardighi and Farakka thermal power plant and cement plant at Sagardighi. There are some small-scale industries-food processing, jute and silk textile, brick construction, handloom, bidi (Indian smoking stick) making, electrical, light engineering, handicrafts, cement, etc. are present in the district.

In the Human Development Report of West Bengal, 2004 published by the UNDP, ranked fifth and Murshidabad ranked 15th out of the 19 districts in terms of Human Development Index (HDI) of the State. The overall health condition of the Burdwan is above Murshidabad and the state's average. The most frustrating feature of both the districts is Income Index, which is 0.29 for Murshidabad and 0.47 for Burdwan. In Gender Development Index (GDI), Burdwan ranks $7^{\text {th }}$ and Murshidabad ranks $16^{\text {th }}$ (HDR of WB, 2004).

Keeping the contrasting socio-economic conditions of both the districts in backdrop, we attempt for a comparative study of the levels of attainment of rural development.

\section{Objectives of the Study}

The objectives of the present study are:

- To examine the levels of attainment of development in the two districts in terms of different socio-economic indicators of rural areas.

- To analyse contribution of different socio-economic indicators towards rural development.

- To suggest measures to improve the indicators those are weak in the districts. 


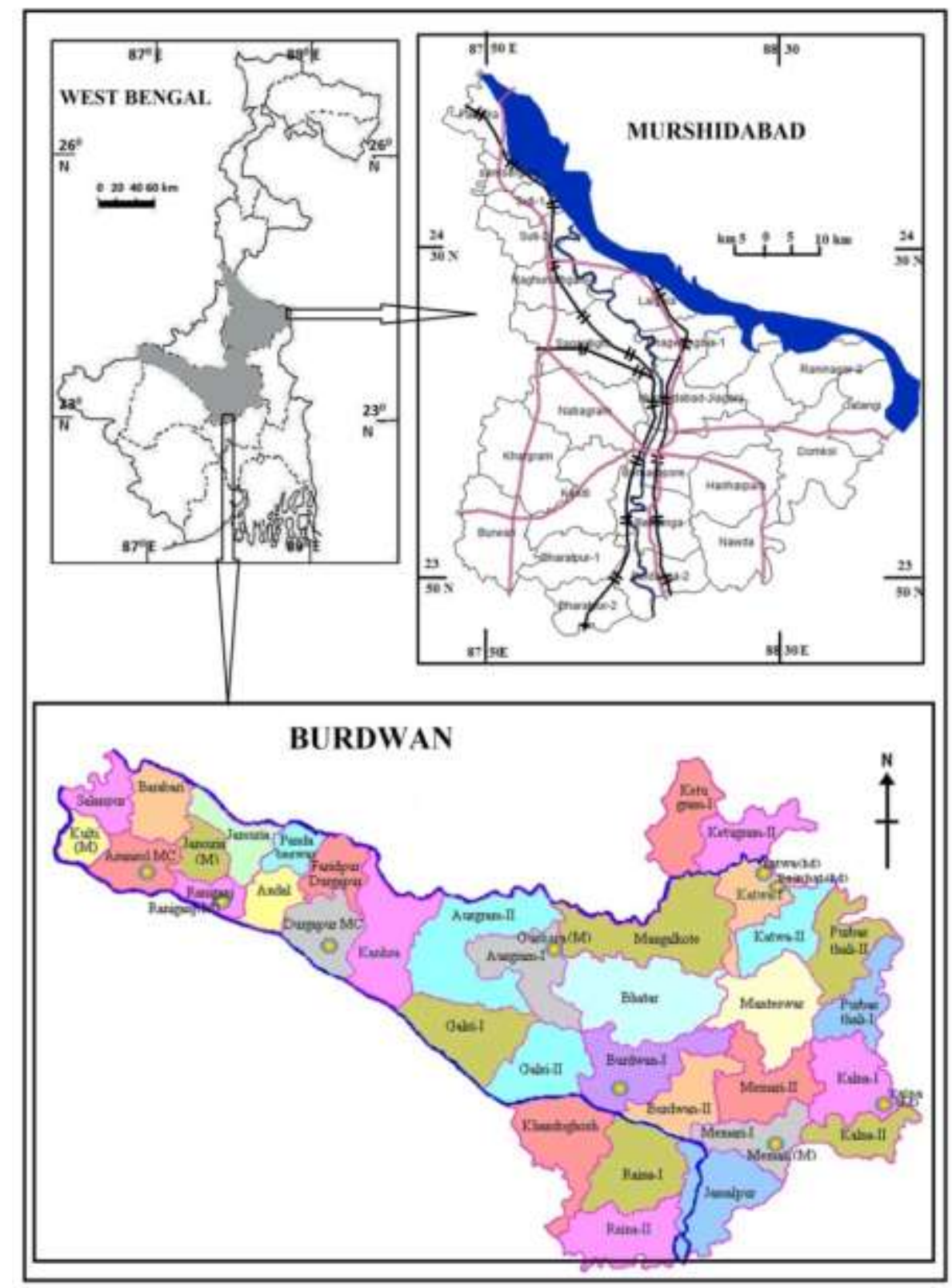

Figure 1: Location Map (Source: Authors)

\section{Sources of Data and Methods of Analysis}

The study is based on secondary sources of data. These are the District Statistical Handbooks (DSHB), District Census Handbooks, Census Tables, Human Development Report of West Bengal and Burdwan, District Level Household Facility Survey (DLHFS) Reports, Economic Review of West Bengal, Report of the Directorate of Agriculture, etc. and other government and non-government reports.
Besides, websites of the respective district are also visited for relevance information.

Different statistical techniques-mean, standard deviation including composite score of development indices have been used to examine and compare the frame of development. Here, we try to analyse the conditions of rural development in the two districts based on 15 indicators (Table 1) falling under four major headings-rural economy and 
poverty, human development indicators, basic infrastructure facilities, standard of living and quality of life. After the individual data based analysis, we combined all the 15 indicators (Table 1) to retrieve composite scores in order to compare the levels of rural development between the two districts of Burdwan and Murshidabad and to do so, five more districtsPurulia, Hoogly, North 24 Paraganas, Coochbihar and Malda are chosen randomly and the Composite Indices are calculated for each district. From the Composite Indices, an average is calculated as the representative Composite Index for the seven districts. Based on the representative Composite Index, percentages of Composite Indices are calculated for each of the seven districts (Tables 2 and 3 ).

$$
\text { Composite Index (C. I. })=\frac{-b \mathrm{Wi} 1 * \mathrm{X} 1+\mathrm{Wi} 2 * \mathrm{X} \ldots \mathrm{Wi} 15 * \mathrm{X} 15}{\mathrm{Wi} 1+\mathrm{Wi} 2+\cdots \ldots \ldots \ldots \ldots \ldots \mathrm{Wi} 15}
$$

\section{Discussions}

The indicators across the sectors constitute the frame of analysis.

\section{Rural Economy}

In both the districts, rural economy is based primarily on agriculture. Therefore, it is obvious to know the condition of agriculture of both the districts. According to the HDR of West Bengal 2004, cropping intensity of Murshidabad is slightly higher than Burdwan (Figure 2; Table 1), because the soils in Burdwan district do not permit to grow multiple crops in a year in the same field. However, for Murshidabad, the situation is quite better as the large tract of Bagri in the eastern part of Bhagirathi has fertile alluvial soil, which helps growing multiple crops. In case of consumption of fertiliser, Burdwan shows higher consumption although growth is negligible (Figure 3; Table 1 ) but decreased in the year 2010-11 for both the districts.

The wage rate shows that Burdwan stands in a better position in terms of agricultural wages (Figure 4; Table 1). In terms of percentage of area, irrigated Burdwan overtakes Murshidabad (Table 1). Increasing wages directly influence upon income and consumption, which has already been stated above and higher in case of Burdwan. Due to low wages, the percentage of migrating labour is higher in Murshidabad (Kundu, 2012). 


\section{Calculation of Composite Indices-Table: 1}

SL no. Indicators of Development

Burdwan Murshidabad Purulia Hooghly N 24 Pgs Coochbihar Malda

\begin{tabular}{|c|c|c|c|c|c|c|c|c|}
\hline 1 & Cropping intensity & 184 & 245 & 123 & 246 & 201 & 220 & 186 \\
\hline 2 & Consumption of fertilisers per hectare $(\mathrm{kg})$ & 219.47 & 135.14 & 33.51 & 268.88 & 142.69 & 70.20 & 201.53 \\
\hline 3 & Agricultural wages & 79 & 69 & 59 & 84 & 78 & 70 & 75 \\
\hline 4 & Percentage of area irrigated, 2005-06 & 38.54 & 21.82 & 21.88 & 60.03 & 31.40 & 20.79 & 28.51 \\
\hline 5 & Rural Work participation rate (male), 2001 & 56.6 & 51.3 & 52.9 & 57.7 & 54.1 & 55.1 & 52.7 \\
\hline 6 & Rural Work participation rate in \% (female), 2001 & 20 & 14.7 & 39.2 & 18.9 & 12 & 23.3 & 29.6 \\
\hline 7 & Rural literacy (\%), 2011 & 73.39 & 66.27 & 63.75 & 79.22 & 78.11 & 73.87 & 60.42 \\
\hline 8 & Rural households availing banking services (\%), 2001 & 33.16 & 22.18 & 27.37 & 32.57 & 28.22 & 15.88 & 23.97 \\
\hline 9 & Percentage of villages having sub centres & 50.0 & 43.2 & 28.9 & 27.3 & 43.5 & 42.2 & 30.4 \\
\hline 10 & Rural per capita consumption (₹), 2000 & 501.58 & 385.69 & 280.15 & 486.9 & 550.84 & 466.43 & 428.67 \\
\hline 11 & Percentage of families living pukka houses, 2005 & 61.25 & 58.24 & 56.42 & 70 & 55.66 & 46.58 & 61.63 \\
\hline 12 & Percentage of Rural households with toilet facilities, 2001 & 26.97 & 17.97 & 4.37 & 38.15 & 53.44 & 23.37 & 16.03 \\
\hline 13 & $\begin{array}{l}\text { Percentage of Surfaced road to } \\
\text { total roads, } 2005-06\end{array}$ & 65.4 & 46.62 & 39.76 & 42.21 & 59.27 & 19.78 & 39.68 \\
\hline 14 & $\begin{array}{l}\text { Proportion of rural households } \\
\text { using safe sources of drinking water, } 2001\end{array}$ & 92.72 & 97.76 & 33.99 & 98.47 & 97.96 & 83.76 & 84.7 \\
\hline 15 & Percentage of Mouza electrified, 2007 & 99 & 97.2 & 86.2 & 100 & 99.6 & 98.2 & 97.7 \\
\hline
\end{tabular}




\begin{tabular}{|c|c|c|c|c|c|c|c|c|c|c|c|c|c|c|c|}
\hline Indicators & 1 & 2 & 3 & 4 & 5 & 6 & 7 & 8 & 9 & 10 & 11 & 12 & 13 & 14 & 15 \\
\hline Total & 1405 & 1071.42 & 514 & 222.97 & 380.4 & 157.7 & 495.03 & 183.35 & 265.5 & 3100.26 & 409.78 & 180.3 & 311.82 & 589.36 & 677.9 \\
\hline Mean & 2007 & 153.06 & 73.42 & 31.852 & 54.342 & 22.528 & 70.718 & 86.663 & 37.928 & 442.89 & 58.54 & 25.757 & 44.545 & 84.194 & 96.84 \\
\hline $\begin{array}{l}\text { Standard } \\
\text { Deviation }\end{array}$ & 42.66 & 83.42 & 8.22 & 13.97 & 2.27 & 9.31 & 7.28 & 6.08 & 8.88 & 89.01 & 7.12 & 16.02 & 14.63 & 22.99 & 4.799 \\
\hline $\begin{array}{l}\text { Weightage } \\
\text { (SD/Mean) }\end{array}$ & 4.71 & 1.83 & 8.93 & 2.28 & 23.89 & 2.42 & 9.71 & 14.24 & 4.27 & 4.97 & 8.22 & 1.61 & 3.04 & 3.66 & 20.18 \\
\hline
\end{tabular}

\section{Table: 3}

Districts

Composite Index

¿C.I.

Mean C.I.

$\%$ of C.I.
Murshidabad 82.12

\subsection{7}

\section{Purulia} 66.31

\section{Hooghly}

95.44

\section{North 24 Paraganas

91.92

592.83

84.69

97

78

113

108

Coochbihar 82.63

Malda 82.79 
DOI: 10.20896/saci.v4i1.196

\section{Demographic Indicators}

Rural sex ratio (sex ratio as per Census of India refers to number of females per 1000 males) is low in both the districts. In 2001 Census, Murshidabad remains in better position than Burdwan in terms of sex ratio. In 2011, both the districts have similar, that is, low sex ratio. This is the sign of overall backwardness of rural people. Rural literacy rate of Burdwan (73.39\%) is higher than Murshidabad (66.27\%).The increase of rural literacy rate is slightly higher in Murshidabad (15\%) than Burdwan (8\%) from 2001 to 2011 (Figure 5; Table 1).

\section{Human Development Indicators}

Per capita income is higher in Burdwan than Murshidabad (Figure 6) (HDR, 2004). In terms of per capita food grains production also, Burdwan overtakes Murshidabad (Figure 7). Position of Burdwan has remained higher for last ten years when compared to Murshidabad. As a result, rank in the per capita domestic product (19992000), Burdwan holds third position, while Murshidabad ranks 15th. Overall, the rural per capita consumption is higher in Burdwan than in Murshidabad (Table 1). In the rural areas too, per capita consumption in Burdwan is ₹ 501.58 whereas in Murshidabad it is ₹ 385.69.

Rural poverty ratio is much higher in Murshidabad than Burdwan (Figure 9). In terms of human poverty index, 2001 too, Murshidabad shows higher index value (Figure 10).

However, as anticipated, health situation in the rural areas of the two districts are poor. Health facilities are not available in every village in both the districts. Only 6-7\% villages have Primary Health Centres (PHCs) and only 15-18\% villages have doctor facilities. Here, the situation of Burdwan is quite better than Murshidabad. Not all villages have Accredited Social Health Activists (ASHA). Only the Anganwadi workers (village level health worker engaged in caring mother and child) are present in $100 \%$ villages in the Murshidabad district and $90 \%$ in Burdwan district.
Altogether, 22 rural hospitals in Burdwan district remain scattered in all the five sub-divisions. In Murshidabad district, there are 17 rural hospitals scattered over in the four subDivisions. Number of beds per lakh population is higher in Burdwan district than in Murshidabad. In Burdwan, it is 96 whereas in Murshidabad it is only 42 (Figure 8 ).

The condition of house in rural areas is very poor. About 50\% rural people in Murshidabad and $40 \%$ in Burdwan live in kuchha (earthen) houses (Figures 11). Only $34.5 \%$ people of Murshidabad and $41.23 \%$ people of Burdwan live in houses with good condition (Figures 12). Extreme forms of poverty are the key reasons for this. The situation of Burdwan is comparatively better. In terms of toilet facilities, although there is an increase in percentages, many rural households in the two districts still lack toilet facilities. In 1991, only $15.32 \%$ and $8.36 \%$ households had toilets in Burdwan and Murshidabad respectively, which increased to almost double in 2001; currently, about $82 \%$ households in Murshidabad and $73 \%$ households in Burdwan have toilets (Figure 14).

\section{Rural Infrastructure}

The most important basic infrastructure in rural areas is road network. There are different types of rural roads under different government organisations such as village roads under panchayat, roads under 'Panchayat Samity' (block-level local Government), roads under Public Works Department (PWD), roads under Zilla Parisad (district-level local government) PMGSY (Pradhan Mantri Gram Sadak Yojana: Prime Minister's rural road development programme), etc. Surfaced all weather road is desirable for better transport and communication. The length of roads maintained by different government authorities' show more surfaced road in Burdwan than in Murshidabad (Figure 15). It is also an indicator of unequal rural development in the two districts. 


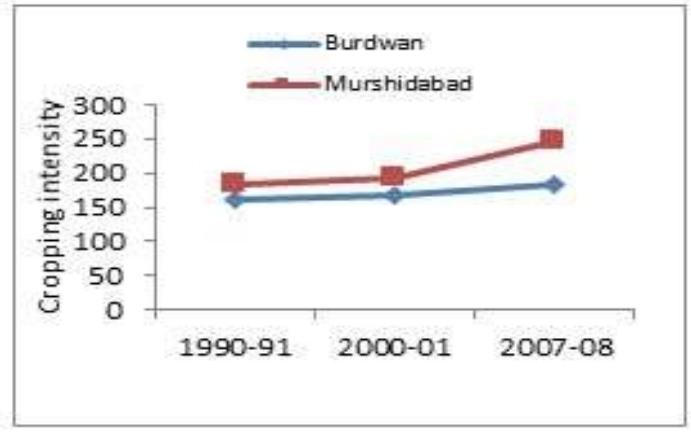

Figure 2: Cropping Intensity

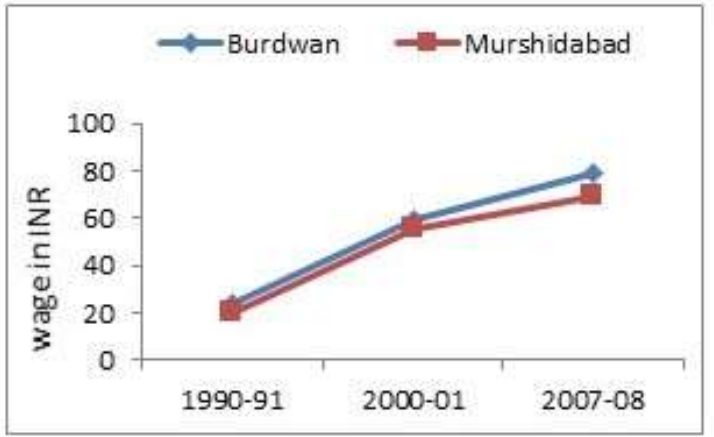

Figure 4: Agricultural Wage Rate for Male

Field Labourers respective to Total

Population

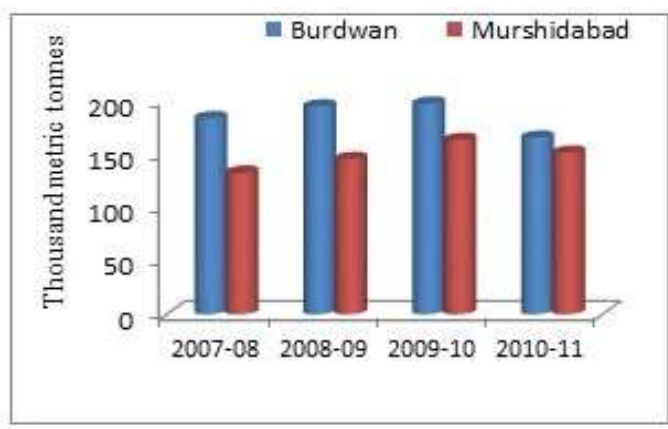

Figure 3: Consumption of Fertilisers

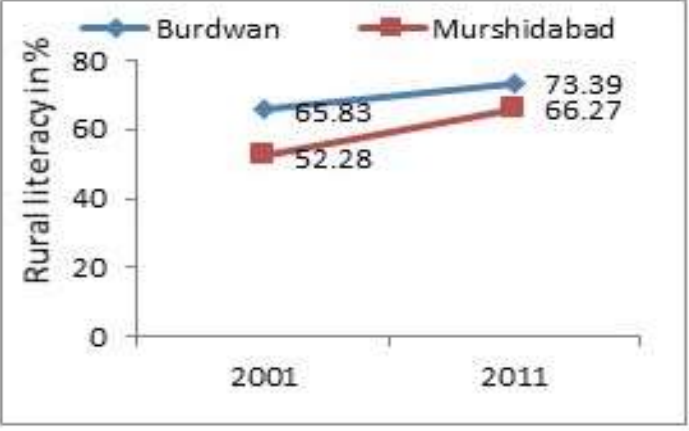

Figure 5: Rural Literacy Rate

Source-Figures 2-5: Economic Review of West Bengal, 2011-2012

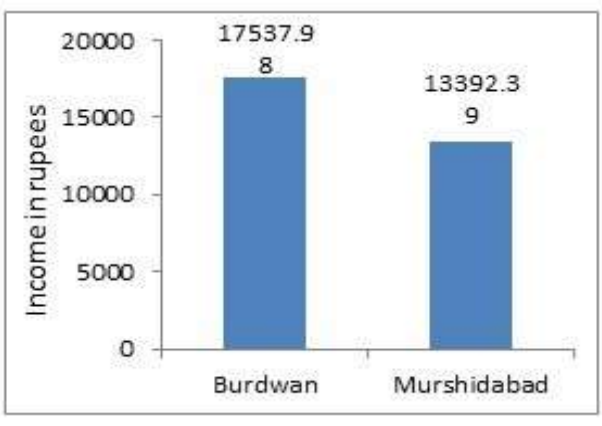

Figure 6: Per Capita Income in Rupees

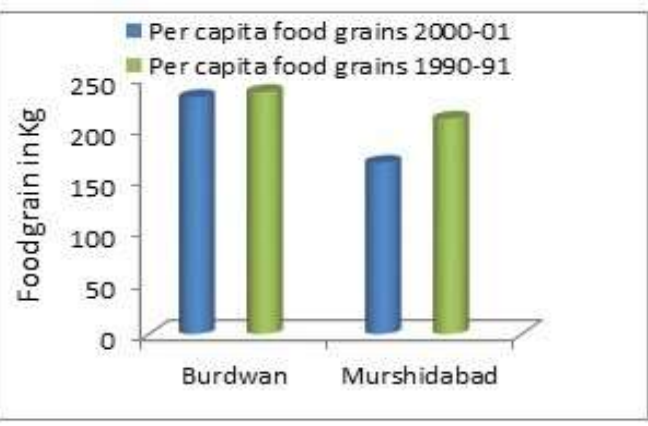

Figure 7: Per capita Food-grain Production Source-Figures 6 and 7: Economic Review of West Bengal, 2011-12

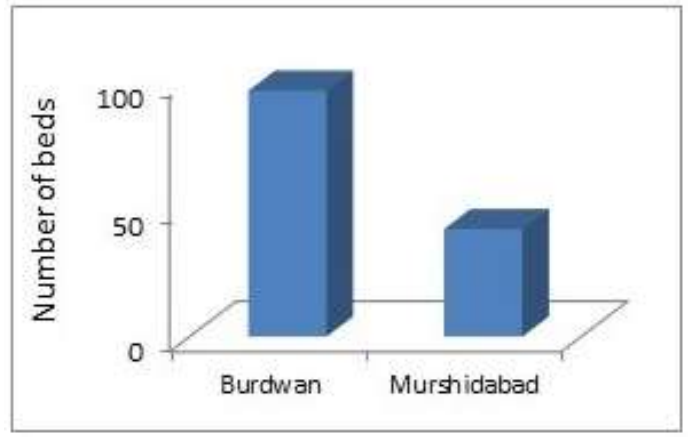

Figure 8: Number of Beds per 100,000 of population

Source: National Health Mission, Ministry of Health \& Family Welfare, Government of India, http://nrhm.gov.in/nrhm-instate/state-wise-information/westbengal.html

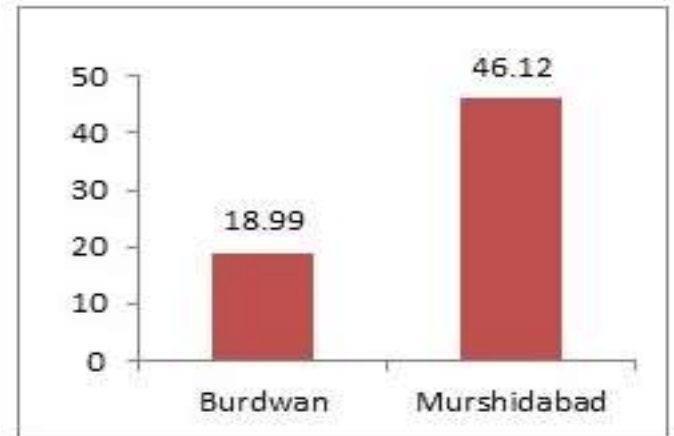

Figure 9: Rural Poverty Ratio (in percentage) Source: Human Development Profiles of Government of West Bengal, 2007 
and DSHB of Burdwan and Murshidabad, 2012

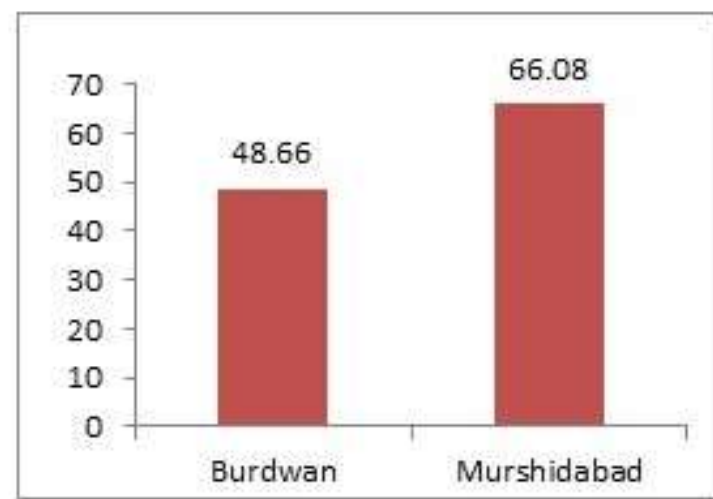

Figure 10: Human Poverty Index, 2001 Source: Human Development Profiles of Government of West Bengal, 2007

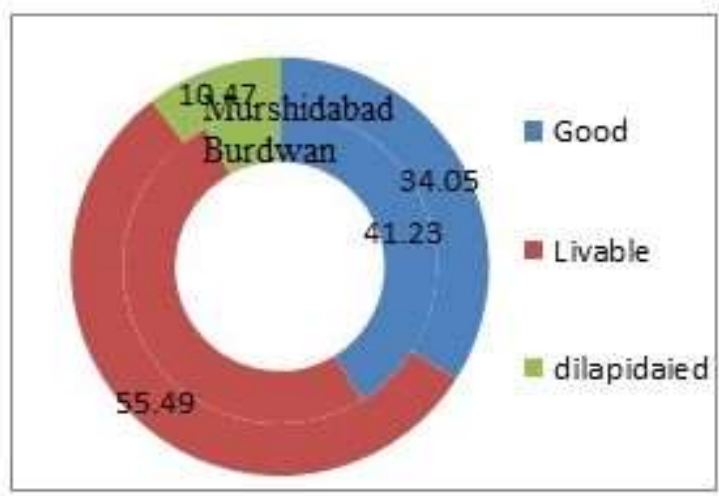

Figure 12: Percentage of Rural Households

Living in Houses by Types, 2001 Source: Census of India, 2001

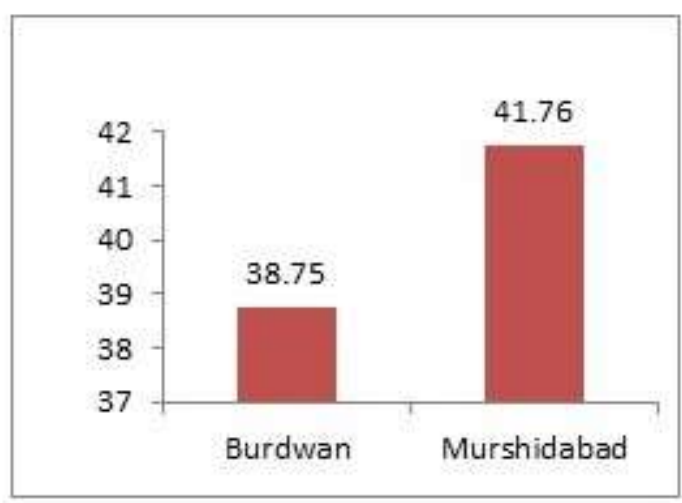

Figure 11: Percentage of Families Living in Kuchha (earthen) Houses

Source: DLHFS-3, 2010

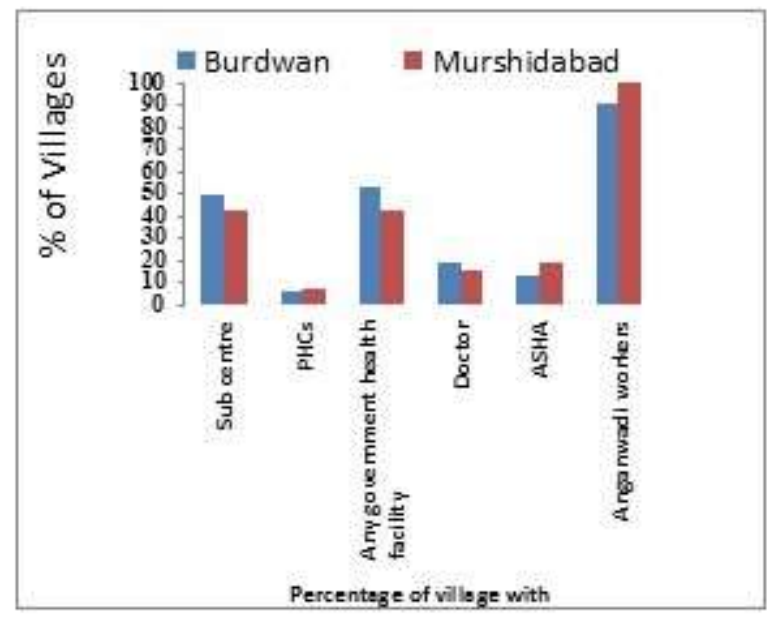

Figure 13: Percentage of Villages with Health Infrastructures

Source: DLHFS of WB, 2007

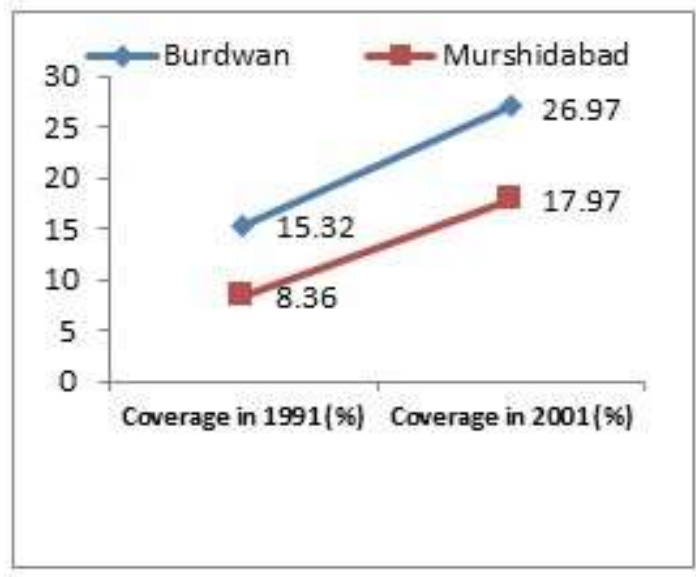

Figure 14: Percentage of Rural Households with Toilet Facilities, Source: Census of India, 2001 


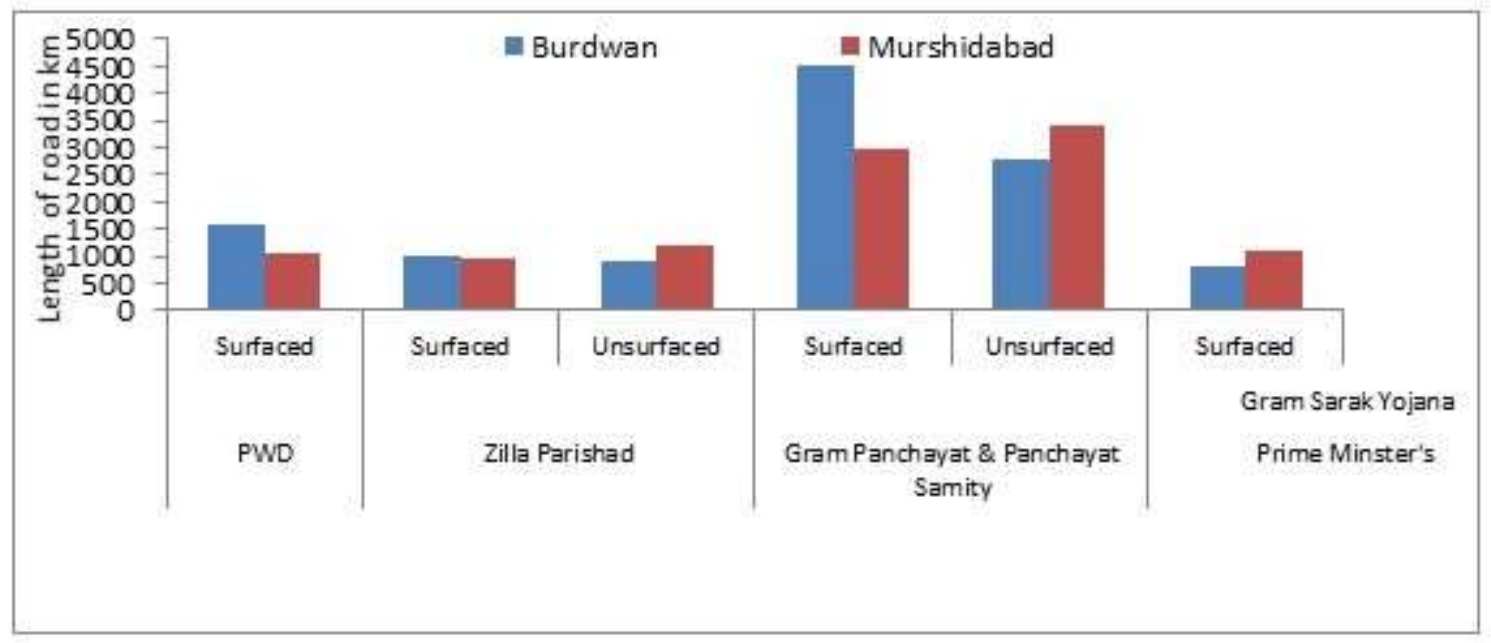

Figure 15: Roads under Different Authorities, Sources: DSHB, 2011 and 2012

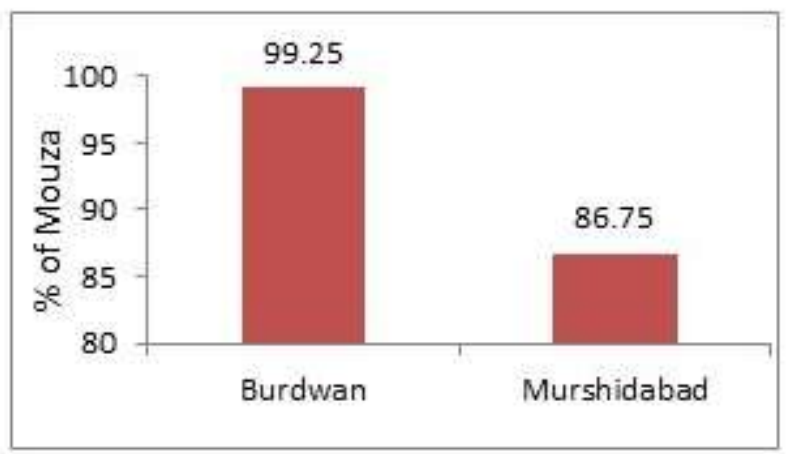

Figure 16: Percentage of Mouzas having Drinking Water Facilities, Sources: DSHB, 2011 and 2012

Power condition of Burdwan is good as it has $100 \%$ villages with electricity connection but in Murshidabad, the connection figure stands at $86 \%$.

The percentage of rural households having bank accounts and availing banking services are meagre. In other words, about $70 \%$ rural people do not have banking services. The overall situation of rural Murshidabad remains appalling with - only $22 \%$ of people avail banking service whereas in Burdwan, it is about $33 \%$. Poor banking service is because of their low economic status and social backwardness. Besides, the people are unaware about the services provided by the banks. Another reason is the lack of sufficient branches of banks in

\footnotetext{
${ }^{1}$ Scheduled Castes and Scheduled Tribe populations are indigenous peoples of India. Clause (1) of article 341 and clause (1) of article 342 of the Constitution of India
}

remote rural areas. For Scheduled Caste (SC), $13 \%$ for Murshidabad and $27 \%$ for Burdwan and Scheduled Tribe (ST), $1.28 \%$ for

Murshidabad and $6.34 \%$ for Burdwan, populations, ${ }^{1}$ the situation is far more dismal.

In $15 \%$ of villages of the Murshidabad district, there are no facilities for drinking water. Even there is a block level variation in the drinking water facility within the district. In Burdwan district, almost all the villages have drinking water facility (see, Figure 16).

\section{Analysis}

From the composite scores (Table 2 and 3 ) of seven selected districts, Murshidabad is in sixth position, just above the Puruliya district, whose

recognises respectively Scheduled Castes and Scheduled Tribes as disadvantaged and marginalised affirming empowerment (Bhattacharyya, 2009; 2013). 
situation is worst. On the other hand, Burdwan occupies second position jointly with North 24 Parganas, just after Hooghly, whose situation is relatively better. The score of Murshidabad is 82.12 , which are below the average value of 84.69 of the seven districts. On the other hand, score of Burdwan is 91.57, which is far above the average score. Therefore, in terms of rural development, though, both the districts are lagging behind, the condition of Murshidabad is relatively worse. Despite several schemes of the Central Government, net progress in rural development has not been attained at the desired level.

\section{Interventions Required}

Although rural Burdwan is comparatively in better condition than Murshidabad but rural areas in both the districts are still underdeveloped. We urge for a bottom-up approach of development for both the districts, as there are many shortcomings in the infrastructures. Income is not sufficient for leading a comfortable life in both the districts. Households having toilet facilities have increased for both the districts but still more requires to be done. In both the districts, health infrastructure facility is poor. Few percentages of rural people in both the districts enjoy banking services. Only ray of hope is that electricity has reached in almost every village.

Based on our research findings, we again reiterate that more emphasis is to be given on the development of infrastructures, which consists of physical and social components (Srinivasan, 2010). Sanitation facility, sound road, power, telecommunication are physical infrastructures and basic education, primary health, and pollution free ambience are social infrastructure. These infrastructures increase access to the rural people, lack of which limits the opportunities that people have to improve and sustain their social and economic well-being (Malayadri, 2010). Of course, proper development of infrastructure in rural areas improves rural economy and quality of life (Kumar, 2006).

Road is the lifeline in the rural areas and a basic infrastructure (Sharma, 2003) that play pivotal role in reducing the spatial disparities. Road network has triggered off a number of infrastructural improvements in the rural areas (Samanta, 2013). Rural poverty can be removed by improving rural roads (Yadav, 2010). Central and state as well as local Governments have important roles to develop this basic infrastructure. Presently, PMGSY is playing important role in constructing all weather roads in the villages but until now, the target of cent percent coverage remains unreached. Besides, the periodic maintenance of the roads is very important for long term socio-economic benefit (Hettige, 2006). In addition to these measures, agro-based industries in Burdwan and tourism in Murshidabad are specially suggested for boosting up the rural development. It may be mentioned in this context that there are many places of tourist attractions in Murshidabad and a considerable number of tourists used to visit this district every year (Tarafder and Jana, 2012). All these can be made possible only through the efficiency of administrative machineries at different levels and appropriate people's participation in the decision-making process for rural development.

\section{References}

Bhattacharaya, R. (2011). Social Correlates of Rural Poverty: Regional Distribution and Effects. Practising Geographer, 15 (2), 118-140.

Bhattacharyya, R., Vauquline, P. and Singh, S. (2011). Towards a Socially Sustainable India: An Analysis of National Rural Employment Guarantee Scheme, 2006. In S.K. Singh, Raj Kumar, H.P. Mathur, N.B. Singh and V.K. Kumra (eds). Energy Resources, Alternative Search and Sustainable Development, New Delhi: Shree Publishers, 73-88, ISBN: 978-81-8329-395-2

Bhattacharyya, R. and Vauquline, P. (2013). A Mirage or a Rural Life Line?: Analysing the Impact of Mahatma Gandhi Rural Employment Guarantee Act on Women Beneficiaries of Assam, Space and Culture, India, 1(1), 83-101, DOI: http://dx.doi.org/10.20896/saci.v1i1.10 (ISSN: 2052-8396).

Bhattacharyya, R. (2009). Examining the Changing Status and Role of Middle Class 
Assamese Women: Lessons from the Lives of University Students, PhD thesis, Newcastle University, UK.

Bhattacharyya, R. (2013). Are We Empowered? Stories of Young Indian Working Women, Saarbrücken, Germany: Lap Lambert Academic Publishing, ISBN: 978-3-659-20580-4.

Chakraborty, P. (2010). Sustainable Rural Development: The Experience of Chitrakoot Project, Madhya Pradesh. Practising Geographer, 14(2), 132-139.

Census Info India 2011

(http://www.devinfolive.info/censusinfodashbo ard/website/index.php/pages/source_lighting/t otal/electricity/IND)

De, N. K. and N. C. Jana (1997). The Land: Multifaceted Appraisal and Management, Sribhumi Publishing Company, Calcutta, 312325.

Desai, V. (1991). Fundamentals of Rural Development: A Systems Approach. Delhi: Himalaya Publishing House, 1.1-1.3.

Fraser, N. (2015). Social Security through Guaranteed Employment, Social Policy \& Administration: An International Journal of Policy and Research, 49 (6), 679-694, DOI: 10.1111/spol.12164

Goswami, C. and Bhattacharyya, M. (2014). Rural Non-Farm Employment in Assam: Trends and Issues, Journal Space and Culture, India, 2 (1), 14-23, DOI:

http://dx.doi.org/10.20896/saci.v2il.38

Government of West Bengal, (2004). West Bengal Human Development Report 2004, Development and Planning Department, GoWB, Kolkata.

Hettige, H. (2006). When do Rural Roads Benefits the Poor and How? An Indepth Analysis based on Case-studies, Asian Development Bank, Philippines, 34.

Kumar, P. (2006). Rural Infrastructure: Thrust Area in Rural Development, Kurukshetra, Ministry of Rural Development, Government of India, 17.
Kundu, S. (2012).Impact of Rural Labour Outmigration on Availability of Labour-force at Source Area: An Opinion Survey in the block of Dumkal, in Murshidabad district, West Bengal, International Journal of Social Science, 1, (2), 204.

Malayadri, P. (2010). Rural Infrastructure: An Engine for Poverty Mitigation. In Kurukshetra, Ministry of Rural Development, Government of India, 16-17.

Planning Commission, Five Year Plans, Government of India Retrieved from: http://planningcommission.nic.in/plans/planrel /fiveyr/welcome.html

Pradhan, S. and A. Ranjan (2010). Corporate Social Responsibility in Rural Development: Evidences from India. School of Doctoral Studies (EU) Journal.

Samanta, G. (2003). Transport Network and Rural Development in Burdwan District, West Bengal. In B. C. Vaidya (eds.) Geography of Transport and Development in India. New Delhi: Concept Publication, 427.

Sharma, S. C., D. N. Tripathi and D. P. Mishra. (2003). The Geographical Study of Transport Network in Amethi Taluk of Uttar Pradesh, In B. C. Vaidya (eds.) Geography of Transport and Development in India. New Delhi: Concept Publication, 450.

Sinha, D. (2016). Tagore and Rural Reconstruction: A Synergy and Implications for Modern Professional Social work Practice, Muse India, Issue 65, Jan-Feb.02.

Srinivasan, G. (2010). Need for Rural Infrastructure Development. In Kurukshetra, Ministry of Rural Development, Government of India of India, 10.

Singh, K. (2014). Rural Development: Principles, Policies and Management, Sage India, 178-242.

Sudarshan, R.M. (2011). India's National Rural Employment Guarantee Act: Women's Participation and Impacts in Himachal Pradesh, Kerala and Rajasthan, CSP Research Report, 06, Institute of Development Studies and Centre for Social Protection. Retrieved from: 
http://www.ids.ac.uk/files/dmfile/ResearchRep ort06FIN AL.pdf

Tarafder, S. and Jana, N. C. (2012). Assessment of Tourism Potential in Murshidabad District, West Bengal, Eastern Geographer, XVIII (1),
Yadav, K. K. (2010). Road Connectivity as a Stimulant for Rural Poverty Reduction. Kurukshetra, Ministry of Rural Development Government of India, 13. 132. 